\title{
The Influence of Globalization on Turkish Sports
}

\author{
Mehmet Şahin \\ Correspondence: Mehmet Şahin, Physical Education and Sport, Mehmet Akif Ersoy University, Turkey. \\ Received: February 5, 2018 \\ doi:10.11114/jets.v6i4.2995 \\ Accepted: February 27, $2018 \quad$ Online Published: March 6, 2018 \\ URL: https://doi.org/10.11114/jets.v6i4.2995
}

\begin{abstract}
This paper addresses the phenomenon of globalization, which has also spread to sports, in terms of its economic, social and cultural aspects; while discussing the concept based on examples from the discipline of football in the premier league of Turkey. In this framework, sports labor emigration mobility is handled, and sponsorship and the effects of globalization in Turkey's sport is examined in terms of relationships between media and sports. The paper also provides concrete examples from the national and international sports circles by framing the fields where globalization becomes apparent in sports. In this framework, this article addresses the sport labor migration, and studies the effect of globalization in Turkish sports within the relations among sponsorship, media and sports.
\end{abstract}

Keywords: globalization, sport labor migration, sponsorship in sports

\section{Introduction}

\subsection{The Concept of Globalization}

Globalization is discussed as a new solution which was developed in order to reestablish capitalism after the 1980s and for capitalism to overcome the last crisis it had experienced (Özer, 2005). It is therefore not possible to treat globalization separately from capitalism and its historical development. Our argument is based on the emergence of capitalism that was born during the time of the demise of feudal relations. It is in effect not a new phenomenon since the geographical discoveries to find new markets were considered as the first step of globalization, and since it started with the discovery of America 500 years ago and has continued with the universality of the Enlightenment (Amin, 1993). Just as capitalism destructed all feudal, patriarchal and rural forms of relations in everywhere it came to power (Marx\&Engels, 1998), today the fact of "social state" is disintegrated along with the globalization of the capital. Globalization is a recently-discovered phenomenon although it has been one of the basic characteristics of the system for centuries since capitalism is global per se (Wallerstein, 1997, p.36). However, the geographical discoveries of our current century are not performed on lands, but on the least developed and developing countries where labor is cheap with no insurance and job security. Globalization also includes the developments in capital and finance movements, and in transportation and communication technologies (Akkaya, 2003). The USA seems to be on the top today hegemonically. This is possibly the reason why the twenty-first century is the American century, just as the nineteenth century was of the United Kingdom: in other words, while modernity is regarded European, post-modernity is regarded American (Taskale, 2005, p. 113). The USA is in the first position outrunning the center countries i.e. the equals (Kazgan, 2002). Due to the domination the USA has secured on the global order by its economic, cultural and military position, globalization is, in a sense, also seen as an Americanization (Giddens, 2000).

\section{Globalization and Sports}

Since we treat globalization as the name of capitalism in our age, it can only be through understanding the sports-capitalism relation that we can comprehend the relations between sports and globalization; because the concept of globalization bears an ideological trait that obscures concrete realities. It is possible to better understand the current era if, rather than this concept, we set out from the concept of the capitalist mode of production, which has a history of about three centuries, class bases and domination mechanisms (Timur, 2004). Capitalism aims to make profit in the field of sports by changing it into an industrial domain (Barut, 2006). Along with the flourishing of globalization, the web of sports businesses has been established with the production, marketing, advertising and trading of sports items as a global domain of distribution. Instrumentalization of sports furthermore secures the continuation of the ideological and cultural hegemony. The best proof that globalization has secured a firm place in sports is the change that has been experienced in the domain of sports in the last two decades. Today, leagues are managed by free market rules (LaFeber, 2001). 
The perception of sports as a typical business has brought with it the management of sports by "free market rules". Large businesses have become interested in sports as sponsors with the recognition the communication and marketing power of sports, and sponsorship in sports has incredibly developed in the last two decades. Even the organization of sports events has become dependent upon cooperation with sponsors. It is estimated that $20 \%$ of football tournaments cannot be held without the support of sponsors (Sahin et al., 2003).

The relation between globalization and sports has such a broad framework that it cannot merely be explained by such mega sports events as the Olympic Games or world cups. As the sports industry thrives, the international sports management and the relations of sports with politics become significant. As sport labor migration increases at the international level, citizens from countries of different socio-economic and cultural structures participate in sports on an unequal footing. Relations of production and consumption of sports items have spread to a global web, and sports is often the one which is controlled in the cooperation with multinational media corporations.

\section{Globalization, Flexible Working in Sports and Sport Labor Migrations}

In the globalization process, multinational corporations prefer least developed or developing countries where labor is cheap. This is why employment of migrants or fugitives has become pretty widespread in the developed countries. Papers that argue that sport labor is transferred from the least developed to the developed countries via illegal channels must be taken into consideration even if they are only allegations for the time being. Researches on sport labor migration which is observed to have started as of 1990s attract gradual attention of scholars, though more research is required compared to other studies on other fields of sociology (Maguire, 2004: 477).

The data in football which can be called "flexible working" have concretized if little. The report on commodification of adolescent football players in Europe which was submitted in November 1999 to the Italian senate stated that the number of footballers coming out of the EU under the age of sixteen who played illegally in amateur clubs was 5,282 (Authier, 2002). While the ratio of players from South Africa and Sub-Saharan Africa to all players in the French professional football was $6.7 \%$ in 1955, this ratio rose to $18 \%$ in 1998 (Andreff, 2004). It becomes clear that the trend today in skill identification in sports is towards a club-based system which increasingly looks to foreign players rather than a nation-based system which attaches more importance to domestic young players. Many European clubs have established collaborations with the sports clubs in the least developed African leagues (Maguire\& Pearton, 2000: 762).

It is a loss of right for the immigrant player from the developing country to receive less salary than the domestic one in the country of destination even though he/she performs the same job. The illegal immigration victimizes the player. There exist examples of this subject. Serge Lebri who was brought to FC Nantes in France when he was fourteen from the Ivory Coast was not only dismissed from the team but also deported as a refugee on the day when he got disabled. The minimum wage of football players in Belgium was 1000 EUR when RAEC Mons hired Georges Moujando from Kamerun in 1996 for 150 EUR per month. The only winner of this transfer is thus the teams. Süleyman Oulare, who was bought for 1000 thousand EUR when he was a kind in Guinea, was then sold for 5,75 million EUR to Fenerbahçe (FB) in 1999 (Topçuoglu, 2006).

Sport labor migration also displays a move to the developed countries from other developed countries, as it involves one from the least developed countries to the developed ones. There are also to be seen aware, determined and prepared immigrants in the examples of football labor migration (Stead\&Maguire, 2000: 53). World Cups show leagues that are popular preferences of immigrant footballers. 343 of the 736 football players of 32 countries in the 2006 FIFA World Cup play in five Western European countries. 101of these play in the UK, 74 in Germany, 61 in Italy, 56 in France, and 51 in Ispanya. It is observed based on these data that talented footballers from various countries of the world are gathered in the UK because of the capital power of its clubs. The teams in Western Europe that collect qualified footballers are also limited: Manchester United, Chelsea, Barcelona, Real Madrid, Bayern München, Milan, Juventus and Inter. These clubs mark the world football market actually. Poor countries, on the other hand, usually sell their qualified and well-trained footballers to the clubs of the rich countries. For instance, all of the permanent football player staff of the Ivory Coast team that it has declared to FIFA play outside the country; in other words they have migrated to another country to work. Based on their declarations to FIFA, the number of football players who play in abroad in the permanent player staff of 23 of certain countries is as follows: Czech Republic 21, Australia 21, Argentina 20, Brazil 20, Togo 20, Ghana 19, Croatia 19, Trinidad and Tobago 19, Paraguay 18. In 19 countries out of 32, more than half of the national team footballers have "immigrant" status (Ozdemir, 2006).

There are some examples of changing citizenship in sports in Turkey in 2006 that were publicly debated. Two Brazilian sportspeople in football obtained Turkish citizenship and changed their names, and were taken into the permanent player staff of the national football team. Marcio Ferreira Perreira Nobre in Beşiktaş (BJK) became Mert Nobre; while Marco Aurelio Brito Das in FB became Mehmet Aurelio.

FIFA accepted a set of regulatory arrangements in 2001 in order to prevent the "muscle migration" of young people. In 
fact FIFA brought these new rules so as to protect the institutions which train young players and to prevent player transfers under the age of eighteen (Andreff, 2005). One of the reasons why the star candidate of 12 years old, Muhammed Demirci, who plays in the sub-structure of BJK in Turkey cannot be transferred to the Spanish club Barcelona is based on the protection of young players by FIFA with its new regulations.

\section{Findings}

There were totally 540 footballers both in 2006 - 2007 and 2013 - 2014 seasons in Turkish premier league called Super League. Of all footballers in 2006 - 2007 season, 399 (73.9\%) were Turkish and 141 (26.1\%) foreigners whereas this number was $389(72.04 \%)$ Turkish and 151 (27.96\%) foreigners in 2013 - 2014 season. The number of foreign footballers in both seasons is relatively close to each other.

There were 39 African footballers in 2006-2007 season. This number decreased to 29 in 2013-2014 season. There were 35 footballers from Brazil in 2006-2007 and this number decreased to 13 in 2013-2014 season. There were 5 footballers in Bulgaria in 2006-2007 whereas there was no footballers from this country in 2013-2014. There were 9 footballers from Serbia and Montenegro; 7 from Argentina; and 6 from Czech Republic. Number of the footballers coming from these three countries were almost the same in both seasons. There were 6 footballers from France; 1 from Portugal and 1 from Bosnia Herzegovina in 2006-2007 season and the numbers has changed as 19 French footballers, 8 Portuguese Footballers and 5 footballers from Bosnia Herzegovina in 2013-2014 season. There were no footballers from Spain in 2006-2007 season; however, 6 footballers from this country played in Super League in 2013 - 2014.

There were footballers from 30 different countries in 2006-2007 season, and this number increased to 33 countries 33 countries in 2013-2014 season. Although, almost more than half of the footballers were from only two countries in 2006-2007, majority of the footballers in 2013 -2014 season were from five different countries. Number of the footballers from top five countries in 2006-2007 season was 96/141 (which was 68.08\% of all foreign footballers) whereas this number decreased to 79/151 (which was 52.31\% of all foreign footballers) in 2013-2014 season for top five countries. These findings show that in 2006-2007 season foreign footballers were from a limited number of countries, however, as for 2013-2014 season, the number of countries increased and footballers came from a variety of countries.

\section{Discussion}

There were 540 footballers in Turkish premier league, The Super League in both 2006-2007 nad 2013-2014 seasons. Of all players in 2006-2007, 399 (73.9\%) were Turkish and the rest 141 (26.1\%) were foreigners. As to 2013-2014 season, There were 389 (72.04) Turkish and 151 (27.96\%) foreign footballers. The number of foreign footballers in both seasons were close to each other.

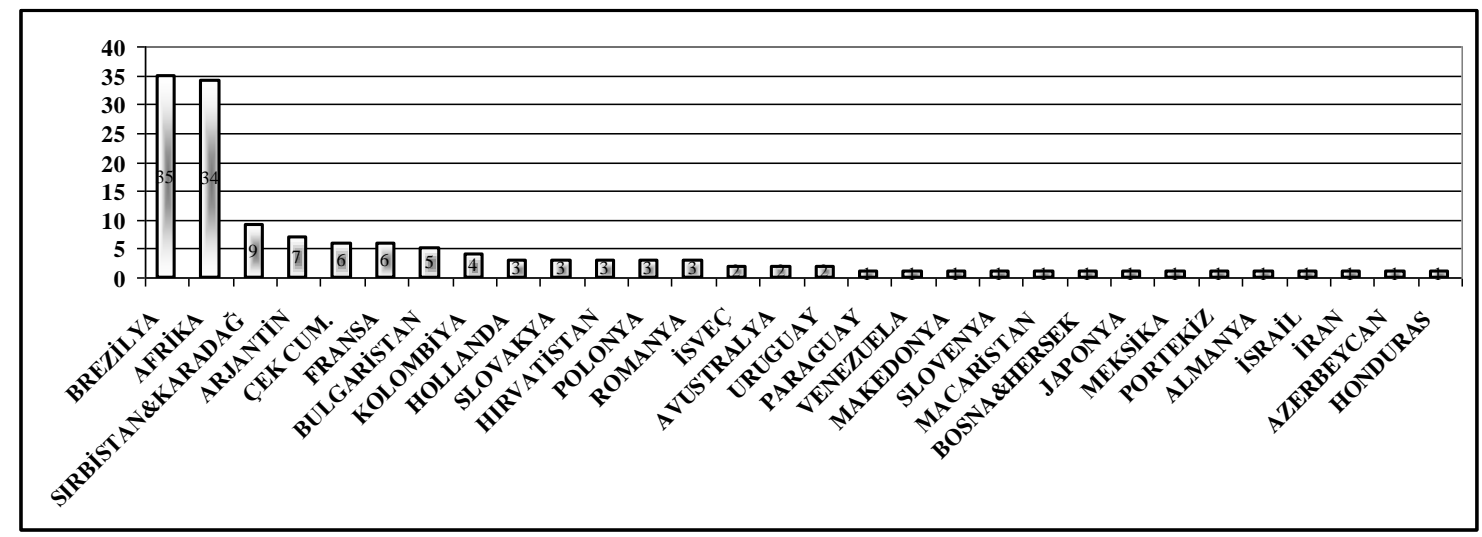

Figure 1. Countries of Migrant Players in the Premier Football League

The main reason for having almost the same rates of foreign footballers in both 2006-2007 and 2013-2014 seasons was can be thought as not changing the quota for foreign footballers. Turkey has had a quota for foreign footballers for many years (Can, 2010). In 2012-2013 season, it was regulated that the clubs could write 8 foreign footballers in the match line up of 18 players, however only 6 of them could play in the match (TFF, 2012). Turkish football clubs have been able to have 10 foreign footballers since 2013-2014 season. However, it was announced that only six of these footballers could be in the match line up of 18 players. (TFF, 2013). According to explanations made by the president of Turkish Football Federation, present situation of foreign footballer quota is $6+0+4$, but it was announced that in 2014-2015 season the quota would be 5+0+3 8 (Demiroren, 2014). From this situation, it can be predicted that the number of foreign footballers in Turkey will probably decrease a little in the future. 
Despite the fact that there were 39 footballers from Africa in 2006-2007 season, the number from this continent decreased to 29 in 2013-2014 season. As for Brazil, the number of footballers from this country was 35 in 2006-2007 but this number decreased to 13 in 2013-2014. There were 5 footballers from Bulgaria in 2006-2007 but no footballers left from this country in 2013-2014 season. There were 9 footballers from Serbia and Montenegro; 7 from Argentina; and 6 from Czech Republic in 2006-2007 season and in 2013-2014, 10 from Serbia, 8 from Argentina and 7 footballers from Czech Republic were playing in Turkey. Number of the players coming from these three countries was almost the same in both seasons. There were 6 footballers from France; 1 from Portugal and 1 from Bosnia Herzegovina in 2006-2007 season and in 2013-2014, 19 French footballers, 8 Portuguese Footballers and 5 footballers from Bosnia Herzegovina played in Turkey. There were no footballers from Spain in 2006-2007 season; however, 6 footballers from this country played in Super League in 2013 - 2014.

Comparing both 2006-2007 and 2013-2014 seasons, it can be seen that the countries the footballers were coming from were varied but there was a consistency and a balance in the number of footballers in both seasons. A demand for high-quality footballers has increased in Turkey as in other countries all around the world in recent years. The desire for being successful both in local leagues and international tournaments of big clubs in Turkey has increased the demand for foreign football players (Dogru, 2008). From this respect, it can be implied that the reason for not having a significant change in the number of foreign footballers in Turkey in recent years might be the desire of clubs for increasing the quality and raise the bar of success.

There might be various underlying reasons of footballers in terms of the countries they come from compared to previous years. The main reason for this is the frequent change of coaches in clubs as the coaches always desire to work with footballers who can play the best in their systems. This condition causes coaches to look for foreign footballers appropriate to their new system in their new club in addition to native players. Furthermore, the economic concerns of clubs in terms of finding affordable players forms the base of foreign footballers coming to Turkey from various countries at different periods. Especially the Turkish football teams that are called Anatolian Teams do not have big budgets for transferring expensive footballers thus they transfer players from some yet little known countries.

It is very well known that the main concern of foreign footballers is the money they will earn from the club they will play for in addition to the popularity of the club. Modern industrial and professional understanding of football requires this. In this framework, the most frequent economic concern of foreign players is the income tax they have to pay while playing football in Turkey. The research conducted by Oz and Akcay (2013) revealed that the income tax paid by foreign footballers in Turkey was relatively lower compared to other countries. For this reason, the fact that the variety of the countries the foreign footballers come from might be due to the wage factor in Turkey should not be ignored.

There were footballers from 30 different countries in 2006-2007 season and 33 in 2013-2014 season. Although, almost more than half of the footballers were from only two countries in 2006-2007, majority of the footballers in $2013-2014$ season were from five different countries. Number of the footballers from top five countries in 2006-2007 season was 96/141 (which was $68.08 \%$ of all foreign footballers) whereas this number decreased to 79/151 (which was $52.31 \%$ of all foreign footballers) in 2013-2014 season for top five countries. These findings show that in 2006-2007 season foreign footballers were from a limited number of countries, however, as for 2013-2014 season, the number of countries increased and footballers came from a variety of countries.

Compared to previous years, in addition to the number of the countries foreign footballers come from, the number of foreign football players has increased in recent years as well in Turkey. Thus, the 132 footballers from various countries playing in Turkey in 2006-2007 increased to 179 in 2013-2014 season (www.transfermarkt.com.tr). The studies on this issue show that the underlying reason on these numbers of foreign players is not the fact that they play better than Turkish players but the lack of enough upbringing facilities and substructures for young players in Turkey (Yıldirım et al., 2012).

While this study forthcoming in Turkey football coach Fatih Terim and TFF President Demirören, "We met so many people, I've done a lot of evaluation. We evaluate the financial structure of our club. According to him, we do certain work. Our management board, and then we met with representatives of Clubs Association Foundation. Non-approval of the club head where the phone was taken. We have received the approval of the decision of the 18 club "where the decision is as follows:

"Decisions will be available in the 2015-2016 season. First, we grant licenses to 28 players. Player of 14 domestic and 14 will be foreign. 14 in domestic players, two sub-structure units, 4 units will be trained in Turkey. If you want to foreigners can be played in 11 of 14 in the first 11. Foreign domestic players wearing the uniform of the national team, will be recognized in foreign status. 7 of the 18 players in the squad domestic and 11 will be foreign. One has the requirement of the Turkish keeper. "The Turkish revolution that decisions as to save football TFF President Demirören " I hope we always move to a better place with our club football, " he says. www.milliyet.com.tr. 06.01.2015. 


\section{Conclusion}

In conclusion, it was found out that the number of the footballers regarding their home countries differ in Turkey and the distribution of foreign footballers in 2006-2007 and 2013-2014 seasons differed from each other. Moreover the number of the foreign players was observed to have increased significantly in 2013-2014 season. The underlying reasons of the variety of the countries the footballers were from were thought to be the fact that the transfer plans of the coaches and the transfer budgets of clubs. In addition to this the desire of clubs in terms of increasing their success and joining international competitions was another motivation for transferring foreign footballers. Deriving from these findings, it can be suggested that in order not to harm native footballer industry, new policies should be developed to train young native footballers and build new infrastructure facilities rather than transferring foreign players.

\section{Suggestions}

1. The canalization of professional Turkish Super League clubs to training native players rather than transferring foreigners and developing new infrastructure programs will contribute to the increase in the number of native footballers in professional teams.

2. Considering the industrial dimensions of football, investments for infrastructure facilities and training programs, and upbringing qualified Turkish players is utmost important. Especially the increase in the number of internationally qualified Turkish players transferred to foreign clubs will contribute to economic development of our clubs.

3. The high astronomically high transfer prices might harm the budget of clubs, and thus the sports economy. For this reason, it will be useful for the clubs to identify transfer policies in accordance with their budgets while transferring foreign players.

4. It is proposed that, as a result of these improvements, sportive success especially in international competitions may be enhanced by also providing positive support to improved sports policies in the country (Uluoz et al., 2016).

5. Income derived from the sport may be evenly shared to the participants in the sport using the game again (Inal, 2008).

\section{References}

Akkaya, Y. (2003). Globalization, unionization and impoverishment. New World Order and Development Congress, Gazi University Faculty of Economics and Administrative Sciences Department of Economics. Ankara.

Amin, S. (1993). Chaos Empire New Capitalist Globalization. Converting: Light Soner. 1st Edition, Istanbul: Analiz Press.

Andreff, W. (2004). Would a Second Transition Stage Prolong the Initial Period of Post-socialist Economic Transformation into Market Capitalism?, European Journal of Comparative Economics, 1(1), 7-31.

Andreff, W. (2005). «Pistes de réflexion économique» (Economic perspectives), in La nationalité dans le sport: Enjeu et problèmes (Nationality in sport: issues and stakes), CIES Conference, Musée Olympique, Lausanne, Novembre (forthcoming).

Authier, C. (2002). Football Inc. Translated by: Ali Berktay. 1.Edition, İstanbul: Book Publishing House.

Barut, M. (2006). Monopoly Capitalism and Sports. Mersin: Friendly Printing House.

Demiroren, Y. (2014). Explanation of foreign quota from Yıldırım Demirören. Sabah Newspaper (06.02.2014). http://www.sabah.com.tr/Spor/Futbol/2014/02/06/yildirim-demirorenden-yabanci-kontenjani-aciklamasi Access Date: 20.04.2014.

Dogan, C. (2008). Popular Culture and Sports / Football. Sociological Notes, (4-5), 13-21.

Dogru, C. (2008). Competition Restructuring in Football and Regulation of Football Labor Market: Fee Tumbling Model. 2nd National Economics Congress, 20-22 February 2008, Izmir.

Erdemli, A. (2002). Sports Philosophy. 1st Edition, Istanbul: E Publications.

Falcon, H. M., Koc, S., \& Yilgin, A. (2003). Physical Education and Sponsorship in Sport. 1st edition, Ankara: Gaziantep Sport Club Sports Education Publications ,Nobel Publication Distribution.

Giddens, A. (2000). The World is Escaping Our Hands, How Globalization Reforms Our Life, Istanbul: Alfa Press.

Giulianotti, R., \& Robertson, R. (2004). The globalization of football. The British Journal of Sociology, 55(4), 545-568. https://doi.org/10.1111/j.1468-4446.2004.00037.x 
Inal, R. (2008). Globalization and Sport. 1st Edition Istanbul: Evrensel Press.

Kazgan, G. (2002). Globalization and Nation-State New Economic Order. İstanbul Bilgi University Press.

LaFeber, W. (2001). Michael Jordan and the New Global Capitalism. Kurdish Publications.

Maguire, J. (2004). Sport Labor Migration Research Revisited. Journal of Sport \& Social Issues, 28(4), 477-482. https://doi.org/10.1177/0193723504269914

Marx, K., \& Engels, F. (1998). Communist Party Manifestos. Universal Publications.

Ozdemir, Y. (2006). Immigrants championship. Access: http://www.universal.net/06/06/28/kose.html\#5. Access date: 22.12.2006.

Ozer, A. (2005). September 11 United States, Turkey and Globalization. 1st edition, Ankara: Ellipse Book.

Perryman, M., \& Marquseel, M. (2006). If our national team does not win, whoever wins. Birgün Newspaper 09.06.2006; 787: 6 .

Sahin, M. (2004). Olympism ideology and criticism. Free University Forum, 2004; 71-72.

Stead, D., \& Maguire, J. (2000). Rite de passage or passage to riches. Journal of Sport \& Social Issues, 24(1), 36-60. https://doi.org/10.1177/0193723500241004

Taskale, R. A. (2005). Where America is transforming from democracy to conservatism. Felsefelogos, 3-4(27-28), 113-114.

Timur, T. (2004). How was Turkey be globalized. 1st edition, Ankara: Image Publications.

Topçuoglu, N. (2006). Developing countries are playing but not winning. Reference Newspaper. 18.06.2006: 31

Uluoz, E., Yılmaz, C. Y., Kavasoglu, I., Gunsel, A. M., \& Dinc, Z. F. (2016). A Study on the Sports Training and Instruction in Turkey: An Overview of Higher Education Programs in the Area of Sports. World Applied Sciences Journal, 34(2), 250-255.

Wallerstein, I. (1997). Interview with Immanuel Wallerstein. Birikim, (104), 36.

Yildirim, E., Sezen, M., Savucu, Y., \& Karatas, O. (2012). Turkey's economic foreign players playing in professional football league, the views from the social and cultural aspects. International Journal of Human Sciences, 9(1), 283-295.

\section{Copyrights}

Copyright for this article is retained by the author(s), with first publication rights granted to the journal.

This is an open-access article distributed under the terms and conditions of the Creative Commons Attribution license which permits unrestricted use, distribution, and reproduction in any medium, provided the original work is properly cited. 